\title{
The "Non-Cumulation" Clause: Policyholders Cannot Have Their Cake and Eat it Too
}

\author{
Jan M. Michaels, ${ }^{*}$ Michael J. McNaughton ${ }^{* *}$ \& Sridevi R. Krishnan ${ }^{* * *}$ \\ Every problem contains the seeds of its own solution. \\ -Stanley Arnold
}

\section{INTRODUCTION}

General liability insurance carriers and policyholders have long wrestled with how to apportion the damages from claims involving bodily injury or property damage happening over long time spans, such as asbestos bodily injury and environmental property damage claims. Such claims are often called "long-tail" claims. Often, the cause and progression of injury or damage involved in such claims is not easy to determine. Policyholders, however, generally have the burden to prove that a loss "triggers" an insurance policy, i.e., that at least some injury or damage leading to the damages for which the policyholder seeks coverage took place during the periods of the relevant policy. ${ }^{1}$ Many courts have recognized that this burden can be difficult or impossible to meet for these types of claims. ${ }^{2}$ This fact has led many courts to accord a presumption to the policyholder that the injury or damage is continuous. ${ }^{3}$ Under this presumption, the injury or damage is deemed to have begun at

* Shareholder, Michaels \& May, P.C., Chicago, Illinois, handling complex commercial and insurance coverage litigation cases including environmental exposure, allocation, products liability, and mass tort. J.D., University of Notre Dame Law School; B.A., State University of New York at Albany.

** Associate, Michaels \& May, P.C., Chicago, Illinois, practicing in areas concerning environmental coverage issues, allocation, mass tort, product liability, and general commercial litigation. J.D., Chicago-Kent School of Law; B.A., University of Chicago.

${ }_{* * *}^{*}$ Associate, Michaels \& May, P.C., Chicago, Illinois. J.D., Loyola University Chicago School of Law; B.A., Benedictine University.

The views expressed in this article belong to the authors alone and do not necessarily reflect those of Michaels \& May, P.C. or its clients.

1. See infra Part IV.

2. See infra Part IV.

3. See Spaulding Composites Co. v. Aetna Cas. \& Sur. Co., 819 A.2d 410, 415 (N.J. 2003) (recognizing that "a growing number of states [] have adopted the continuous trigger theory"). 
some appropriate point (such as the date of first exposure to asbestos in asbestos bodily injury claims, or the date that the polluting operations began in pollution property damage claims) and then to have happened continuously until some other appropriate date (such as the date of diagnosis or death in asbestos claims, or the date on which the cleanup is complete in pollution claims). ${ }^{4}$

Once courts resolve the trigger of coverage issue through the presumption of continuous injury or damage, the question becomes who should pay for what portions of the relevant damages. In the typical type of claim, there is little doubt as to the date on which injury or damage happened. Accordingly, typical claims generally do not raise issues regarding which insurance policy covers the claim, if any (so long as concurrent insurance, which is insurance covering the same time period, is not involved). However, with respect to long-tail claims, there often is no actual evidence of damage or injury during the policy period, let alone evidence of how much injury or damage happened in any given period. In this context, insurers and policyholders have locked horns over the appropriate method for allocating liability for these claims.

With some exceptions, many insurers take the position that the plain language in these policies limits the scope of coverage to only those damages that the policyholder is liable to pay because of injury or damage happening during the policy period. These carriers point out that the continuous injury or damage trigger provides no basis for concluding that any more or less injury or damage took place in any one part of the continuous trigger period than another. Accordingly, to honor the plain meaning of the contract language, these insurers assert that the only legitimate method for allocating liability for these claims is to prorate the damages by spreading them evenly across the entire presumptive period of continuous injury or damage. This approach is generally known as "pro rata allocation." 5

Most policyholders take a different view. Naturally, their goal is to maximize recovery under their insurance programs. In pursuing this goal, however, policyholders often take contradictory positions.

4. See, e.g., Lincoln Elec. Co. v. St. Paul Fire \& Marine Ins. Co., 210 F.3d 672, 689-90 (6th Cir. 2000) (explaining that the continuous injury trigger theory creates a rebuttable presumption that all policies in effect from exposure to the manifestation are triggered); Broderick Inv. Co. v. Hartford Accident \& Indem. Co., 742 F. Supp. 571, 573 (D. Colo. 1989) (adopting continuous trigger method and finding that each policy issued during the period that damage occurred was triggered).

5. See infra notes $51-60$ and accompanying text. 
Historically, policyholders have argued that the only legitimate way to apportion damages under general liability policies is to apply a contractual version of joint and several liability, generally known in the insurance context as "all sums" liability. ${ }^{6}$ In arguing for this approach, policyholders often point to the prior insurance and non-cumulation of liability clauses (non-cumulation clauses) that are often found in commercial general liability (CGL) policies. These clauses generally provide that the limits of liability under a policy are reduced by the sums due under any prior insurance policies that insure the same loss. Policyholders argue that, because these clauses refer to the possibility that earlier and later policies might cover the same loss, the existence of these clauses proves that insurers always have understood that CGL policies cover damages arising from bodily injury or property damage happening outside their policy periods.

Over the years, all sums liability has gained some traction with courts in certain jurisdictions. Now, policyholders and their advocates, who had previously used these non-cumulation clauses to obtain all sums rulings, seek to avoid the consequences of the application of these same clauses in the all sums context. One key premise of this argument is that the non-cumulation clauses resulted from the transition in the 1960s from CGL policies that insured "accidents" to policies insuring "occurrences." The earlier, accident-based policies were triggered when the "accident," or the event causing the relevant injury or damage, happened during the policy period. ${ }^{7}$ Under the newer occurrence-based policies, it was the injury or damage itself, rather than its cause, that had to take place during the policy period to trigger coverage. ${ }^{8}$ Thus, the transition from accident-based to occurrence-based policies raised the possibility that both an earlier accident-based policy and a later occurrence-based policy would cover the same loss. Policyholders are now using this historical context to argue that the non-cumulation clause only applies in this situation and does not apply in the all sums context.

In a 2011 article, The "Non-Cumulation Clause": An "Other Insurance" Clause by Another Name, Christopher C. French seeks to use this argument to avoid the impact of non-cumulation clauses in those

6. See infra notes $61-67$ and accompanying text.

7. See infra Part III.

8. The authors note that these generalizations are not substitutes for an analysis of the relevant policy language at issue in a particular case. For instance, and by way of example only, in their practice the authors have encountered some policies that require both the injury or damage and the occurrence - the cause of the injury or damage - to happen during the policy period to trigger coverage. 
jurisdictions that have accepted all sums liability. ${ }^{9} \quad$ Mr. French asserts that the archetypal non-cumulation clause, drafted in the 1960s, was intended solely to address the accident-to-occurrence transition. According to Mr. French, the sole purpose of the clause was to avoid situations in which an insurer had to pay under both an earlier, accidentbased policy (because the cause of the injury or damage happened during its policy period) and under a later, occurrence-based policy (because the resultant injury or damage happened during that policy period). The drafters, Mr. French claims, did not anticipate later developments in insurance law, such as all sums liability or the continuous trigger theory. ${ }^{10}$ Accordingly, Mr. French maintains, the non-cumulation clause is "hopelessly ambiguous" and is nothing more than a rebranded "other insurance" provision. ${ }^{11}$

Mr. French's article and the arguments it raises reflect the belated realization by policyholders that they may have thrown out the baby with the bathwater when they argued that the non-cumulation clause supports all sums liability. The problem, from the policyholder's perspective, is that the application of the non-cumulation clause under an all sums regime may, in some circumstances, actually reduce a policyholder's insurance recoveries to a sum lower than it would recover under the pro rata allocation approach.

However, by its plain language, the non-cumulation clause applies in the all sums context. Even considering its historical origins, the language of the non-cumulation provision plainly applies to any situation in which earlier and later general liability policies apply to the same loss. If these clauses were intended to apply only to the narrow situation that Mr. French identifies, they would have been much more narrowly crafted.

Through their advocacy, policyholders have persuaded some courts to create a liability framework under the all sums approach that is closely analogous, if not identical, to precisely the situation that gave rise to the need for non-cumulation clauses in the first place. Accordingly, the situation under the all sums framework falls squarely within the scope of these clauses. Therefore, policyholders must now lie in the bed they made: non-cumulation clauses, which policyholders have used to achieve in some jurisdictions the all sums result they desire, do and should apply

9. 60 U. KAN. L. ReV. 375 (2011).

10. Id. at 387.

11. Id. at 404 . 
in the all sums context. If they do not, then they are irrelevant to the all sums versus pro rata liability dispute in the first instance.

This Article proposes that policyholders apply non-cumulation clauses erratically and inconsistently. Section II discusses some of the characteristics of long-tail claims and the difficulties involved in pinpointing how much of the injury or damage giving rise to such claims happened in any particular time period. Section III recounts the evolution of the standard CGL policy. Section IV summarizes two competing methods for assigning liability for long-tail claims, both among insurers and as between insurers and policyholders: pro rata allocation and all sums liability. Section V summarizes policyholders' use of the non-cumulation clause in CGL policies to persuade certain courts to adopt the all sums liability approach. Section VI summarizes and rebuts key arguments made in Mr. French's article, The "NonCumulation Clause": An "Other Insurance" Clause by Another Name. Finally, Section VII sets forth arguments supporting the conclusion that the non-cumulation clause is unambiguous and should apply in the all sums context.

\section{LONG-TAIL CLAIMS}

\section{A. The Concept of Long-Tail Claims}

Consider a scenario in which a hypothetical corporation, ABC Corp., has conducted manufacturing operations at a site from 1950 to 1980. A score of different carriers issued occurrence-based policies with consecutive policy periods to ABC Corp. In this hypothetical, waste escaped ABC Corp.'s facility in 1950 and leached into adjacent groundwater shortly after operations began. This groundwater contamination continued until 1980, when ABC Corp. learned of the contamination and ceased operations. This pollution, which progressively contaminated the environment throughout this period, resulted in ABC Corp. being liable for millions of dollars in governmentmandated cleanup and pollution monitoring costs. Moreover, ABC Corp. faces tens of millions of dollars in liability to individuals who suffered bodily injury, property damage, or both, as a result of exposure to the contaminated groundwater during the operations period and long after operations ceased.

ABC Corp.'s liabilities result from bodily injury and property damage happening over more than three decades. Assuming no coverage defense applies, which of ABC Corp.'s liability insurers must bear the cost of these liabilities? To maximize its recovery, ABC Corp.'s risk 
managers will seek to recover under each general liability policy in effect throughout the pollution period, contending that the relevant damage and injury triggers all policies issued during the pollution period.

\section{B. Primary Types of Long-Tail Claims}

The above hypothetical illustrates a hallmark of long-tail claims: the delay, or latency period, between the causal event and the manifestation of injury or damage resulting from that event. The most common types of long-tail claims are toxic exposure (usually asbestos) and environmental contamination claims.

Asbestos-related disease claims are perhaps the most common longtail bodily injury claims. ${ }^{12}$ The versatility of asbestos led to its widespread use in industry and commerce, particularly in construction. ${ }^{13}$ Asbestos use began in the 1860s and rapidly expanded. ${ }^{14}$ Asbestos fibers can become airborne and lodge in the lungs when inhaled. ${ }^{15}$ Certain types of asbestos have been proven to cause cancer and various pulmonary diseases when inhaled. ${ }^{16}$ These diseases take a long time to develop; it often requires years of asbestos inhalation for the disease to develop, and symptoms generally manifest years after exposure ceases. ${ }^{17}$

12. See, e.g., Global Reinsurance Corp. v. Equitas Ltd., 969 N.E.2d 187, 189 (N.Y. 2012) (asbestos claims "surface long after the policy period").

13. See Ins. Co. of N. Am. v. Forty-Eight Insulations, Inc., 633 F.2d 1212, 1214 (6th Cir. 1980) (noting that asbestos possesses a high tensile strength and flexibility and withstands high temperatures, such that it is conducive to many commercial uses).

14. See In re Joint E. \& S. Dist. Asbestos Litig., 129 B.R. 710, 735-39 (E.D.N.Y. \& S.D.N.Y. 1991), vacated, 982 F.2d 721 (2d Cir. 1992) (providing a comprehensive historical background of asbestos use and the discovery of its detrimental health effects).

15. See, e.g., id. at 737 (discussing the expected peak of asbestos-related deaths in the 1990s and 2000s due to embedded asbestos particles in millions of workers' lungs).

16. See id. at 737-42 (referencing asbestos-induced detrimental health effects like mesothelioma, bronchogenic carcinoma, and asbestosis).

17. See A.W. Chesterton Co. v. Mass. Insurers Insolvency Fund, 838 N.E.2d 1237, 1251 n.11 (Mass. 2005) ("Because the injurious effects of asbestos may not be apparent, or capable of medical diagnosis, for many years after initial exposure, the questions 'what is bodily injury' and 'when does it occur' often assume primary importance in insurance coverage disputes involving asbestos.”); In re Liquidation of Integrity Ins. Co., No. C-0063-03, 2012 WL 1314181, at *9 (N.J. Super. Ct. App. Div. Apr. 18, 2012) (noting that injury from asbestos exposure is not "quick to manifest, but instead, may remain unrecognized for substantial periods of time, thereby rendering uncertain the ultimate liability that will accrue to an insured”); Jamaica D. Potts \& Kenneth S. Rivlin, Not So Fast: The Sealed Air Asbestos Settlement and Methods of Risk Management in the Acquisition of Companies with Asbestos Liabilities, 11 N.Y.U. ENVTL. L.J. 626, 631-32 (2003) (explaining that mesothelioma, a fatal cancer of the outer lung and chest cavity caused by prolonged inhalation of asbestos, may occur up to forty years after exposure to asbestos fibers). 
This latency period often implicates decades' worth of CGL policies, long after they were issued and their policy periods ended.

Environmental contamination claims present the same sort of continuous injury and delay in manifestation as asbestos-related long-tail claims present. Environmental contamination frequently entails damage occurring over an extended period that triggers multiple policies issued over a period of years or decades. ${ }^{18}$ The fact that such damage is happening may go unrecognized or ignored for much of the pollution period. The hypothetical scenario described above is typical of such claims.

With respect to these long-tail claims, it is generally necessary to answer three questions to efficiently and equitably apportion liability among multiple insurers and between the insurers and the policyholder. First, when did the injury or damage commence? Second, when did the injury or damage cease? Third, and most crucially, what is the amount of injury or damage that happened in each year ${ }^{19}$ Unfortunately, with regard to the third of these basic questions, it is inherently difficult (and often impossible) to quantify what portion of continuing injury or damage spanning several decades took place in any given year. ${ }^{20}$ Yet policyholders, insurers and, ultimately, the courts have to resolve these questions, and the financial consequences of the answers are often immense. $^{21}$

18. See Farmers Mut. Fire Ins. Co. v. N.J. Prop.-Liab. Ins. Guar. Ass'n, Nos. L-0619-09, L1004-09, 2011 WL 2671583, at *3 (N.J. Super. Ct. App. Div. July 11, 2011) (“The problem with environmental contamination claims is that the damage that triggers insurance liability will not occur due to a single event, but 'usually is attributable to events that begin, develop and intensify over a sustained period of time [and] [t]herefore, the damages ha[ve] occurred or been triggered along a continuous timeline during which several successive policies issued to the insured were in effect.'”) (alteration in original) (quoting Quincy Mut. Fire. Ins. Co. v. Borough of Bellmawr, 172 N.J. 409, 416-17 (2002)).

19. See Michael G. Doherty, Allocating Progressive Injury Liability Among Successive Insurance Policies, 64 U. CHI. L. REV. 257, 258 (1997) (alluding to the scientific impossibilities in allocating liability to each policy in long-tail claims for injuries happening only within each insurer's respective policy period); William R. Hickman \& Mary R. DeYoung, Allocation of Environmental Cleanup Liability Between Successive Insurers, 17 N. KY. L. REV. 291, 292 (1990) (deeming it "virtually impossible" to correlate degrees of damage to particular policies where successive policies are implicated); James F. Hogg, The Tale of a Tail, 24 WM. Mitchell L. REV. 515, 525-26 (1998) (describing how claims for progressive injury have raised questions of proof as to when the injury occurred, how long the injury continued, and whether there was a single occurrence or multiple occurrences).

20. See Doherty, supra note 19, at 257-58 (observing that many injuries occur over long periods of time, making it sometimes scientifically or administratively impossible to allocate damages to multiple insurance policies).

21. See id. at 258-59, 265. 


\section{THE CGL POLICY AND THE STRUCTURE OF COMMERCIAL INSURANCE PROGRAMS}

The CGL policy was introduced in January 1941 in response to the increasingly urgent need to make insurance less variable. ${ }^{22}$ Accordingly, the CGL policy was created to insure, under a single policy, many of the types of liability exposure arising from a policyholder's locations and business activities. ${ }^{23}$ CGL insurance typically requires the insurer to defend the policyholder in suits arising from potentially insured losses (at the primary insurance level), and to indemnify the policyholder for damages resulting from such losses. ${ }^{24}$ CGL policies were crafted so as to insure legal liability stemming from various types of conduct unless excluded. $^{25}$ Throughout the 1940s and 1950s, considerable changes were made to key phrases, terms, and exclusions in the basic CGL policy form. ${ }^{26}$ Standard CGL policies initially insured only bodily injury liability. However, over time, property damage liability also came to be included. ${ }^{27}$

The allure of CGL policies stemmed from their general uniformity; a generally standardized "form" policy, which applied to a wide variety of business ventures, had the potential to increase efficiency and to enable insurers to rely on the courts' uniform interpretation of the same policy language in evaluating risk. ${ }^{28}$ Because they were designed to address a wide variety of business risks and liabilities, the CGL policy necessarily employed generic language. ${ }^{29}$ Over time, policyholders would seek to exploit this feature by advocating various interpretations to support findings of ambiguity in order to expand the scope of coverage. ${ }^{30}$

22. George B. Flanigan, CGL Policies of 1941 to 1966: Origins of Product Liability, CPCU EJournal, Aug. 2005, at 1, 1; see also Am. Home Prods. Corp. v. Liberty Mut. Ins. Co., 565 F. Supp. 1485, 1500-03 (S.D.N.Y. 1983), aff'd as modified, 748 F.2d 760 (2d Cir. 1984) (discussing the origin and purpose of general liability policies, which evolved "out of the difficulties faced by courts and parties in dealing with personal injuries and property damage sustained as a result of gradual processes").

23. James A. Robertson, How Umbrella Policies Started Part 2: The First Umbrella Forms, IRMI (Apr. 2000), http://www.irmi.com/expert/articles/2000/robertson04.aspx?.

24. Sharon M. Murphy, The "Sudden and Accidental" Exception to the Pollution Exclusion Clause in Comprehensive General Liability Insurance Policies: The Gordian Knot of Environmental Liability, 45 VAND. L. REV. 161, 163-64 (1992).

25. See generally Robertson, supra note 23.

26. See generally Flanigan, supra note 22.

27. Robertson, supra note 23.

28. Murphy, supra note 24, at 164 .

29. Id.

30. See, e.g., Harleysville Mut. Ins. Co. v. Packer, 60 F.3d 1116, 1121 (4th Cir. 1995) (“An ambiguity does not exist simply because terms are not defined in the policy.”); E. Associated Coal 
Before 1966, CGL policies employed an "accident” trigger. Under the accident trigger, the accident (the cause of the injury or damage leading to liability) must happen during the policy period for the policy to potentially cover liability arising from the accident (subject to other policy provisions). The insuring agreements in these pre-1966 policies typically contained language resembling the following:

To pay on behalf of the insured all sums which the insured shall become obligated to pay by reason of the liability imposed upon him by law, or assumed by him under contract as defined herein, for damages, including damages for care and loss of services, because of bodily injury, sickness or disease, including death at any time resulting therefrom, sustained by any person or persons and caused by accident. ${ }^{31}$

Moreover, these accident-based policies often contained "Policy Period/Territory" provisions or other contract language explicitly limiting coverage to accidents taking place during the applicable policy periods. ${ }^{32}$

Thereafter, this language was subjected to recurring judicial scrutiny. Since the policy did not define the term "accident," much of this scrutiny centered on whether an accident had to be a "sudden" event, or whether it could be gradual or progressive. ${ }^{33}$ One of the more troubling aspects for courts interpreting the pre-1966 accident-based policies was determining whether injuries or property damage caused by gradual events or processes were caused by "accidents." "34

Corp. v. Aetna Cas. \& Sur. Co., 632 F.2d 1068, 1075 (3d Cir. 1980) (“A court should not torture the language of the policy in order to create ambiguities.”); Consol. Edison Co. v. United Coastal Ins. Co., 628 N.Y.S.2d 637 (N.Y. 1995) ("The court should not find the language ambiguous on the basis of the interpretation urged by one party, where that interpretation would 'strain the contract language beyond its reasonable and ordinary meaning." (quoting Broadway Nat'l Bank v. Progressive Cas. Ins. Co., 775 F. Supp. 123, 126 (S.D.N.Y. 1991) (internal quotation marks omitted)).

31. See Flanigan, supra note 22 (providing sample form language of early CGL policies); Hogg, supra note 19, at 526 (discussing the evolution of CGL policies from accident-based to occurrence-based).

32. See, e.g., Kirkham, Michael \& Assocs. v. Travelers Indem. Co., 493 F.2d 475, 476 (8th Cir. 1974) ("This policy applies only to accidents which occur during the policy period.” (internal quotation marks omitted)); Protex-A-Kar Co. v. Hartford Accident \& Indem. Co., 227 P.2d 509, 510-11 (Cal. Dist. Ct. App. 1951) (same); EnergyNorth Natural Gas, Inc. v. Underwriters at Lloyd's, 848 A.2d 715, 723 (N.H. 2004), aff'd, 452 F.3d 44 (1st Cir. 2006) (same).

33. James M. Fischer, Insurance Coverage for Mass Exposure Tort Claims: The Debate Over the Appropriate Trigger Rule, 45 DRAKE L. REV. 625, 633 (1997) (discussing courts' construction and interpretation of "accident," such that an accident was often required to constitute a sudden event with occasional exceptions for incremental, progressive losses); Hogg, supra note 19, at 527 (discussing whether an accident had to be a "sudden and episodic event").

34. Am. Home Prods. Corp. v. Liberty Mut. Ins. Co., 565 F. Supp. 1485, 1500-01 (S.D.N.Y. 
In response, the Insurance Services Office (ISO) ${ }^{35}$ revised the standard liability form in 1966, creating an "occurrence-" based policy that subsumed the concept of an "accident" within the occurrence definition to provide greater clarity regarding coverage for gradual, progressive losses. ${ }^{36}$ Accordingly, the standard CGL policy subsequently incorporated the following language into its 1966 insuring agreement, which is the key provision in CGL policies that spells out the basic scope of coverage: "The Company will pay on behalf of the Insured all sums which the Insured shall become legally obligated to pay as damages because of bodily injury or property damage to which this insurance applies caused by an occurrence ....."

In 1966, “[o]ccurrence” was defined to mean: "an accident, including injurious exposure to conditions, which results, during the policy period in bodily injury or property damage neither expected nor intended from the standpoint of the Insured." 37

ISO's 1973 revisions to the CGL policy further clarified the temporal limitations within the policies. The insuring agreement from the 1973 CGL policy form reads as follows: "We will pay those sums that the insured becomes legally obligated to pay as damages because of 'bodily injury' or 'property damage' to which this insurance applies . ...”38 The occurrence definition was further revised in 1973 to include "continuous or repeated exposure to conditions," thereby attempting to eliminate any residual concerns that arose from the use of the term "accident.",39

Moreover, ISO's 1973 revisions to the CGL policy moved the requirement that the injury or damage occur during the policy period to be covered from the "occurrence" definition to the "bodily injury" and "property damage” definitions, as follows:

1983), aff'd as modified, 748 F.2d 760 (2d Cir. 1984).

35. The ISO is the entity responsible for overseeing revisions to the CGL coverage form and making it available for use by individual insurance companies. See INTERNAL RISK MGMT. INST., INC., IRMI ON COMMERCIAL GENERAL LIABILITY 13 (2009), http://www.webce.com/pdf/IRMI_C GL_V3.pdf.

36. See Fischer, supra note 33, at 633; Hogg, supra note 19, at 527-28.

37. See Fischer, supra note 33, at 634 n.29 (emphasis added) (quoting John J. Tarpey, The New Comprehensive Policy: Some of the Changes, 33 Ins. Coun. J. 223, 223 (1966)).

38. Fischer, supra note 33, at 633, n.28.

39. Hogg, supra note 19, at 529. 
"[B]odily injury” [means] bodily injury, sickness or disease sustained by any person which occurs during the policy period, including death at any time resulting therefrom. ${ }^{40}$

"Property damage" means (1) physical injury to or destruction of tangible property which occurs during the policy period, including the loss of use thereof at any time resulting therefrom ....

Thus, using the property damage definition as an example (and eliminating the "loss of use" language from the definition), the insuring agreement reads as follows when the definition is plugged in where the defined phrase appears:

The company will pay on behalf of the insured all sums which the insured shall become legally obligated to pay as damages because of [physical injury to or destruction of tangible property which occurs during the policy period] to which this insurance applies, caused by an occurrence. ${ }^{42}$

Additionally, many of these policies include a provision specifying that the policies only cover bodily injury or property damage that occurs during the policy period. ${ }^{43}$ Thus, under their plain language, these policies insure damages because of injury or damage happening during the policy period. ${ }^{44}$

Occurrence-based policies proved enticing to policyholders seeking coverage for asbestos or environmental contamination claims. In the context of these claims, the latency period has enabled policyholders to

\footnotetext{
40. In re Wallace \& Gale Co., 385 F.3d 820, 834 (4th Cir. 2004).

41. Riehl v. Travelers Ins. Co., 772 F.2d 19, 20 (3d Cir. 1985).

42. Sandoz, Inc. v. Emp'rs Liab. Assurance Corp., 554 F. Supp. 257, 259 (D.N.J. 1983) (emphasis added).

43. See, e.g., Aetna Cas. \& Sur. Co. v. Abbott Labs., Inc., 636 F. Supp. 546, 547 (D. Conn. 1986); Sandoz, Inc., 554 F. Supp. at 259.

44. See Ins. Co. of N. Am. v. Forty-Eight Insulations, Inc., 633 F.2d 1212, 1224-25 (6th Cir. 1980) (stating that policies indemnify for liability incurred as a result of an accident or occurrence that occurs during, not outside, the policy period); Sec. Ins. Co. v. Lumbermens Mut. Cas. Co., 826 A.2d 107, 121 (Conn. 2003) ("Neither the insurers nor the insured could reasonably have expected that the insurers would be liable for losses occurring in periods outside of their respective policy coverage periods.”); Consol. Edison Co. of N.Y., Inc. v. Allstate Ins. Co., 774 N.E.2d 687, 695 (N.Y. 2002) ("[T] he policies provide indemnification for liability incurred as a result of an accident or occurrence during the policy period, not outside that period."); 6B J. APPLEMAN \& J.A. Appleman, Insurance LAW AND Practice § 4254, at 26-27 (Rev. ed. 1979) (explaining that insurance policies insure against the risk that the insured will be held liable for injury or damage during the policy period, and do not insure against all risks per se); 7 LEE R. RUSS ET AL., COUCH ON INSURANCE § 102:2 (3d ed. 1995) ("It is a time-honored principle that the insurer's obligation to pay is contingent on a covered loss occurring during the policy period.”).
} 
seek coverage under their historical occurrence-based liability policies, even though the injury or damage manifested decades after the relevant policy periods ended. ${ }^{45}$ The courts found it difficult to consistently interpret the term "occurrence" and to gauge the nature and extent of complex losses involving claims made decades after the cause of the injury or damage in question took place. This problem, among others, led to the development of "claims-made" policies in the $1980 \mathrm{~s}^{46}$

\section{APPORTIONING LIABILITY FOR LONG-TAIL CLAIMS}

Naturally, policyholders seeking coverage for long-tail claims have urged the courts to interpret the CGL policy language so as to maximize coverage. In connection with the 1966 and 1973 ISO forms, they generally do this by emphasizing the prefatory phrase "all sums," found at the beginning of the insuring agreements in these forms, while ignoring the rest of the insuring agreements and the definitions of the relevant terms it contains, in violation of fundamental contract construction principles. ${ }^{47}$

The policyholder usually bears the burden of proving that the damages for which it seeks coverage fall within the scope of the insuring agreement. ${ }^{48}$ As part of that burden, the policyholder must prove that the

45. See, e.g., John M. Sylvester, Insurance Coverage for Long-Tail Liabilities: Recent Trends and Concerns, in INSURANCE LAW 2012, at 61 (Aspatore 2012), available at 2012 WL 697231, at *1 ("For example, a claimant who has just been diagnosed with mesothelioma ... may assert a claim against a company, alleging exposure to asbestos involving the company's products or premises that may have commenced thirty to forty years ago, or more. Companies that are confronted with such long-tail liabilities have taken some comfort in the fact that they ... had purchased historical liability insurance policies on an 'occurrence' basis in earlier decades that specifically provided coverage for these types of liabilities.”).

46. Although beyond the scope of this Article, claims-made policies gradually eclipsed the occurrence-based policies that had reigned throughout much of the evolution of the standard general liability (GL) policy. See generally Fischer, supra note 33 (discussing the evolution of claims-made policies and their implications).

47. See, e.g., Galgano v. Metro. Prop. \& Cas. Ins. Co., 838 A.2d 993, 997 (Conn. 2004) (noting that although ambiguities in a policy are to be construed against the insurer and in favor of the insured, where policy language is plain, courts cannot "indulge in a forced construction ignoring provisions or so distorting them as to accord a meaning other than that evidently intended by the parties”); Alberto-Culver Co. v. Aon Corp., 812 N.E.2d 369, 379 (Ill. App. Ct. 2004) (“By injecting 'commercial' into the [policy provision], the written language supplied and the risks contemplated in writing the policy would be supplanted and distorted unnecessarily, creating an unintended class of insureds.”); Hingham Mut. Fire Ins. Co. v. Smith, 865 N.E.2d 1168, 1172 n.6 (Mass. App. Ct. 2007) ("To adopt the interpretation advocated by the [insureds] would distort the plain meaning of the clause and is contrary to what an 'objectively reasonable insured, reading the relevant policy language, would expect to be covered.”' (quoting New Eng. Mut. Life Ins. Co. v. Liberty Mut. Ins. Co., 667 N.E.2d 295, 297 (Mass. App. Ct. 1996))).

48. See, e.g., Rotella v. Mid-Continent Cas. Co., No. 3:08-CV-0486-G, 2008 WL 2694754, at 
damages for which it seeks coverage are because of injury or damage taking place during the policy period. ${ }^{49}$ However, when the claim at issue involves injury or damage spanning multiple policy periods, determining which policies should pay for what portion of the injury or damage presents substantial difficulties. It is often difficult or impossible to determine how much injury or damage took place during any given period, and one often cannot identify precisely when the injury or damage began and ended. ${ }^{50}$ Accordingly, courts have landed upon different approaches to apportioning liability for these claims. The two primary competing approaches are (1) pro rata by "time on the risk" allocation and (2) "all sums," or joint and several liability.

Pro rata allocation relieves policyholders of their burden to prove the precise amount of injury or damage that happened in each policy period while honoring the insuring agreements in these policies. ${ }^{51}$ In essence, pro rata by time on the risk divides the total damages by the number of years during which injury or damage took place and allocates the resulting sum to each year. ${ }^{52}$ Thus, the policies in each year are

*3 (N.D. Tex. July 10, 2008) (noting that the insured bears the burden of proving that the claimed damages occurred during the policy period); Port Auth. v. Affiliated FM Ins. Co., 245 F. Supp. 2d 563, 582 (D.N.J. 2001) ("The insured bears the burden of demonstrating physical damage or loss manifesting within the pertinent policy period in order to demonstrate a relevant loss.”); St. Michael's Orthodox Catholic Church v. Preferred Risk Mut. Ins. Co., 496 N.E.2d 1176, 1178 (Ill. App. Ct. 1986) (noting that the insured has the burden of proving that a loss falls within the terms of the policy); Harford Cnty. v. Harford Mut. Ins. Co., 610 A.2d 286, 295 (Md. Ct. Spec. App. 1992) ("The burden to show that property damage occurred within the coverage of the policies is ... . upon the insured.”); Ratner v. Canadian Universal Ins. Co., 269 N.E.2d 227, 230 (Mass. 1971) (accepting as a general principle that plaintiff seeking to recover for breach of insurance policy agreement "must allege and prove the cause of action is within the contract's terms"); Am. States Ins. Co. v. Mathis, 974 S.W.2d 647, 649 (Mo. Ct. App. 1998) (noting that the policyholder has the burden of showing that a policy covers the loss and damages at issue and that the insurer must show the applicability of any exclusions); Chase Manhattan Bank, N.A. v. Travelers Grp., Inc., 702 N.Y.S.2d 60, 60 (N.Y. App. Div. 2000) (same), aff'd as modified, 743 N.Y.S.2d 867 (N.Y. App. Div. 2002) (mem.); Garrett v. Pilot Life Ins. Co., 128 S.E.2d 171, 173 (S.C. 1962) (same); Kozlik v. Gulf Ins. Co., 673 N.W.2d 343, 347 (Wis. Ct. App. 2003) (the policyholder must prove that the damages at issue fall within the scope of the insuring agreements).

49. See Rotella, 2008 WL 2694754, at *3 (stating that the insured must show the cause of action arose within the policy's scope of coverage).

50. See, e.g., Outboard Marine Corp. v. Liberty Mut. Ins. Co., 670 N.E.2d 740, 748 (Ill. App. Ct. 1996) (discussing when insurance coverage is triggered in asbestos cases); Benjamin Moore \& Co. v. Aetna Cas. \& Sur. Co., 843 A.2d 1094, 1102-03 (N.J. 2004) (discussing coverage of a single occurrence with multiple-year effects); Soc'y Ins. v. Town of Franklin, 607 N.W.2d 342, 346 (Wis. 2000) (discussing the "exposure" and "continuous trigger" theories in determining when a policy is triggered).

51. See Doherty, supra note 19, at 278-79 (discussing the insurer's liability under pro rata coverage).

52. See, e.g., id. at 281. 
responsible for the damages allocated to that year, and only those damages. ${ }^{53}$ This allocation approach is easy to administer. A court need only determine the total in damages and the period of time over which the injury or damage happened. ${ }^{54}$ Moreover, the pro rata method permits any party to seek to rebut the presumption that the injury or damage happened evenly over the relevant period, if that party concludes that it can prove a more accurate amount of injury or damage that took place in a particular period. ${ }^{55}$

Thus, pro rata allocation holds insurers responsible only for the damages arising from that portion of the injury or damage that is reasonably presumed to have happened during their policy periods. ${ }^{56}$ This approach both honors the contract language and is inherently equitable. ${ }^{57}$ With an "intuitive, common sense appeal," the simplicity of pro rata allocation promotes judicial efficiency. ${ }^{58}$ The approach also minimizes needless litigation costs by eliminating the need for follow-on, protracted, and complex contribution litigation among insurers. ${ }^{59}$ Several jurisdictions have adopted pro rata allocation in light of its deference to the policy language. ${ }^{60}$

53. Id.

54. Id.

55. See, e.g., Ins. Co. of N. Am. v. Forty-Eight Insulations, Inc., 633 F.2d 1212, 1224-25 (6th Cir. 1980) (allowing any party to prove specific years of exposure); Sec. Ins. Co. v. Lumbermens Mut. Cas. Co., 826 A.2d 107, 121 (Conn. 2003); Outboard Marine Corp. v. Liberty Mut. Ins. Co., 670 N.E.2d 740, 749 (Ill. App. Ct. 1996); Boston Gas Co. v. Century Indem. Co., 910 N.E.2d 290, 312 (Mass. 2009); Arco Indus. Corp. v. Am. Motorists Ins. Co., 594 N.W.2d 61, 69 (Mich. Ct. App. 1998), aff'd, 617 N.W.2d 330 (Mich. 2000).

56. See Boston Gas Co., 910 N.E.2d at 353 (describing pro rata allocation "as a trigger of coverage and as a limitation on the promised 'all sums' coverage").

57. See Arco Indus., 594 N.W.2d at 69-70 (discussing the intent of drafters of CGL policies to provide coverage for the policy period alone and not for damages arising prior or subsequent to this period).

58. Doherty, supra note 19, at 282.

59. Id. at 271.

60. See, e.g., Nationwide Ins. Co. v. Cent. Mo. Elec. Coop., 278 F.3d 742, 748 (8th Cir. 2001); Olin Corp. v. Ins. Co. of N. Am., 221 F.3d 307, 324-25 (2d Cir. 2000); Spartan Petroleum Co. v. Federated Mut. Ins. Co., 162 F.3d 805, 812 (4th Cir. 1998); Gulf Chem. \& Metallurgical Corp. v. Associated Metals \& Minerals Corp., 1 F.3d 365, 371-73 (5th Cir. 1993); Commercial Union Ins. Co. v. Sepco Corp., 765 F.2d 1543, 1544 (11th Cir. 1985); Forty-Eight, 633 F.2d at 1224-25; Pub. Serv. Co. v. Wallis \& Cos., 986 P.2d 924, 939-40 (Colo. 1999); Lumbermens Mut. Cas. Co., 826 A.2d at 123; Sentinel Ins. Co. v. First Ins. Co. of Haw., Ltd., 875 P.2d 894, 918 (Haw. 1994); Outboard Marine Corp., 670 N.E.2d at 748; Atchison, Topeka \& Santa Fe Ry. Co. v. Stonewall Ins. Co., 71 P.3d 1097, 1134 (Kan. 2003); Aetna Cas. \& Sur. Co. v. Commonwealth, 179 S.W.3d 830, 842 (Ky. 2005); Norfolk S. Corp. v. Cal. Union Ins. Co., 859 So. 2d 201, 297-98 (La. Ct. App. 2003); Mayor of Balt. v. Utica Mut. Ins. Co., 802 A.2d 1070, 1101-04 (Md. Ct. Spec. App. 2002); Boston Gas Co., 910 N.E.2d at 312; Arco Indus., 594 N.W.2d at 69; N. States Power Co. v. Fid. \& Cas. Co., 523 N.W.2d 657, 662-64 (Minn. 1994); Mallinckrodt Inc. v. Cont’l Ins. Co., Cause No. 
In contrast, the all sums approach potentially holds each triggered policy responsible for the entirety of the damages, regardless of how much of the injury or damage giving rise to those damages happened during its policy period (subject to the policy limits). ${ }^{61}$ The inequity of this approach is apparent. For instance, under this approach a single insurer, providing only one year of insurance, can be required to shoulder damages arising from injury or damage happening over the course of years or decades. ${ }^{62}$ This is true even if the relevant injury or damage began only during the last minute of an insurer's policy period. The all sums approach also often requires insurers to cover periods during which the policyholder elected not to obtain insurance, or to self-insure, or chose to obtain insurance from a carrier that subsequently became insolvent, an outcome often criticized by courts. ${ }^{63}$ The all sums approach ignores the policy language and requires policies to pay for damages incurred because of injury or damage that happened well before and well after their policy periods. ${ }^{64}$ At bottom, all sums permits policyholders to "rewrite" their insurance contracts in order to unilaterally expand the scope of coverage.

Those arguing for the all sums approach often claim that insurers are better situated to bear the entirety of the loss and seek contribution from each other. ${ }^{65}$ However, all sums imposes broader costs and burdens. For

05CC-001214 (Mo. Cir. Ct. of St. Louis Cnty. Nov. 8, 2012); Dutton-Lainson Co. v. Cont’l Ins. Co., 778 N.W.2d 433, 445 (Neb. 2010); EnergyNorth Natural Gas, Inc. v. Certain Underwriters at Lloyd’s, 934 A.2d 517, 527 (N.H. 2007); Owens-Ill., Inc. v. United Ins. Co., 650 A.2d 974, $993-95$ (N.J. 1994); Consol. Edison Co. of N.Y., Inc. v. Allstate Ins. Co., 774 N.E.2d 687, $694-95$ (N.Y. 2002); Sharon Steel Corp. v. Aetna Cas. \& Sur. Co., 931 P.2d 127, 140-42 (Utah 1997); Towns v. N. Sec. Ins. Co., 964 A.2d 1150, 1167 (Vt. 2008).

61. See, e.g., Keene Corp. v. Ins. Co. of N. Am., 667 F.2d 1034, 1047 (D.C. Cir. 1981) (finding insurance company liable in full despite the possibility that the insured's disease developed outside the policy period).

62. Doherty, supra note 19, at 271.

63. See, e.g., Olin, 221 F.3d at 324 ("Olin, paying no premiums to INA, was either uninsured or self-insured. Allocation is appropriate to prevent Olin from imposing liability on INA for injuries that occurred during those periods and arose largely from accidents during these periods in which Olin was not paying for coverage.”); Pub. Serv. Co., 986 P.2d at 940 (“[T] the notion that one single insurance policy among 20 or 30 years worth of policies could be expected to be held liable for the entire time period. Nor is it reasonable to expect that a single-year policy would be liable, for example, if the insured carried no insurance at all for the other years covered by the occurrence.”).

64. See Arco Indus., 594 N.W.2d at 69 (rejecting an all sums approach that would unfairly require the carrier to pay for damages occurring outside the policy period, and thereby contravene explicit policy language).

65. See, e.g., Royal Globe Ins. Co. v. Indus. Accident Comm’n, 403 P.2d 129, 132 (Cal. 1965); Kuhn v. Grant Cnty., 439 P.2d 155, 162 (Kan. 1968). 
instance, an insurer that is forced to bear the entirety of a loss arising from decades of injury or damage must seek contribution from other insurers in separate lawsuits, leading to unnecessary litigation costs and imposing substantial burdens on the courts. ${ }^{66}$ Additionally, in contrast to the predictability of pro rata allocation, the all sums method compels insurers to account for the possibility that they will be held liable for damage or injury occurring beyond the policy period in calculating the premiums they charge. ${ }^{67}$

\section{HistoricAlly, POLICYHOLDERS HAVE USED THE NON- CUMULATION ClAUSE TO SUPPORT ALL SUMS LIABILITY}

By their plain terms, non-cumulation clauses limit the policyholder's ability to recover for the same loss under multiple, successively issued policies. Policyholders have sought to use these clauses to argue in favor of all sums liability, contending that the clauses reflect the insurers' understanding that CGL policies cover liability for injury or damage taking place outside of the policy period. ${ }^{68}$

\section{A. Origins of the Non-Cumulation Clause}

Our understanding of the origins of the non-cumulation clause is consistent with Mr. French's. The initial purpose of the clause was to prevent policyholders from recovering under both accident- and occurrence-based policies for the same loss. ${ }^{69}$ Initially, following the transition from accident-based to occurrence-based policies, it was possible for both an earlier accident-based policy and a later occurrencebased policy to apply to the same loss. ${ }^{70}$ This situation would arise when the cause of the injury or damage happened during the period of the earlier, accident-based policy, and the injury or damage itself happened during the period of the later, occurrence-based policy. ${ }^{71}$ Recognizing this problem, underwriters developed non-cumulation clauses, such as

\footnotetext{
66. Doherty, supra note 19, at 271.

67. Id. at 271-72.

68. See, e.g., Hercules, Inc. v. AIU Ins. Co., 784 A.2d 481, 493-94 (Del. 2001) (explaining how the provision at issue "undercuts the rationale for pro rata allocation"); Viking Pump, Inc. v. Century Indem. Co., 2 A.3d 76, 125 (Del. Ch. 2009) ("The other courts that have explicitly addressed this issue have found non-cumulation and prior insurance provisions to be evidence that the parties did not intend the pro rata method of allocation.”).

69. French, supra note 9, at 387-88.

70. Id. at 386-87.

71. Id.
} 
the one in London Market policy form "L.R.D. 60," written in 1960 by Leslie R. Dew. ${ }^{72}$ Specifically, Mr. Dew sought to ensure that earlier policies written on the accident-based policy form would be required to pay before a later occurrence-based policy. ${ }^{73}$ Accordingly, the new clause precluded the policyholder from seeking coverage under both policies for a single claim. ${ }^{74}$ The non-cumulation clause in CGL policies typically reads as follows:

It is agreed that if any loss covered hereunder is also covered in whole or in part under any other excess policy issued to the Assured prior to the inception date hereof the limit of liability hereon as stated in Item 2 of the Declarations shall be reduced by any amounts due to the Assured on account of such loss under such prior insurance. ${ }^{75}$

\section{B. Policyholders' Use of the Non-Cumulation Clause to Convince Courts to Adopt All Sums Liability}

In arguing for all sums liability under CGL policies for long-tail claims, policyholders have alleged, and continue to assert, that the noncumulation clause shows that insurance carriers understood these policies covered injury or damage happening outside their policy periods.

For example, Chicago Bridge \& Iron Co. v. Certain Underwriters at Lloyd's, London was an environmental coverage dispute involving about fifty years of pollution caused by the policyholder's lumber processing operations. ${ }^{76}$ In addressing the allocation of liability between the policyholder and the insurer, the court held that the non-cumulation provision would be superfluous if the drafters had intended that damages be allocated only among insurers based on their respective time on the risk. $^{77}$

Similarly, the court in Hercules, Inc. v. AIU Insurance Co. addressed an insurance coverage dispute involving forty-three insurers in connection with environmental actions involving decades of pollution from twenty manufacturing sites scattered across the United States. ${ }^{78}$

\footnotetext{
72. Id. at 386 .

73. See id. at 386 ([T]he drafters included the non-cumulation clause on the new LRD 60 policy form to prevent a policyholder from obtaining a double recovery ....”).

74. Id. at 386-87.

75. See, e.g., Teck Metals, Ltd. v. Certain Underwriters at Lloyd's, London, 735 F. Supp. 2d 1231, 1238 (E.D. Wash. 2010); Chicago Bridge \& Iron Co. v. Certain Underwriters at Lloyd's, London, 797 N.E.2d 434, 441 (Mass. App. Ct. 2003).

76. 797 N.E.2d 434, 436 (Mass. App. Ct. 2003).

77. Id. at 441 .

78. 784 A.2d 481, 485 (Del. 2001).
} 
The Hercules court held that the non-cumulation provision, which it specifically characterized as an all sums provision, extended coverage "beyond the policy period in the case of continuing damage."79

More recently, in Viking Pump, Inc. v. Century Indemnity Co., the Delaware Court of Chancery was tasked with addressing how to allocate damages for asbestos-related bodily injury taking place over many years. $^{80}$ In concluding that all sums liability applied, the Viking Pump court asserted that the non-cumulation provision would apply when "the same occurrence gives rise to personal injury ... which occurs partly before and partly within any annual period of this policy." ${ }^{\text {"1 }}$ In its analysis of the non-cumulation clause, the Court of Chancery also concluded that such provisions "cannot be reconciled with the pro rata method of allocation.,"82

\section{The Impact of the Non-Cumulation Clause in the All Sums Liability Context}

Over the years, policyholders have achieved limited success in convincing some courts to adopt the all sums approach. ${ }^{83}$ Having achieved this goal, however, insureds have belatedly realized that the non-cumulation provision, on which they often rely in arguing for all sums, can reduce or prevent recovery for long-tail claims in the all sums context.

For example, consider the following hypothetical. A policyholder has incurred \$30 million in environmental liability due to six years of pollution at one of its plants. For purposes of this hypothetical, over the years the policyholder obtained a mix of primary and excess insurance, with policy periods during the relevant pollution period. The policies provide a total of $\$ 10$ million in limits the first year, with those limits increasing up to $\$ 25$ million by the sixth year:

\footnotetext{
79. Id. at 493-94.

80. Viking Pump, Inc. v. Century Indem. Co., 2 A.3d 76, 107 (Del. Ch. 2009).

81. Id. at 122 .

82. Id. at 123 .

83. See, e.g., Hercules Inc., 784 A.2d at 489; Allstate Ins. Co. v. Dana Corp., 759 N.E.2d 1049, 1058 (Ind. 2001); Goodyear Tire \& Rubber Co. v. Aetna Cas. \& Sur. Co., 769 N.E.2d 835, 840 (Ohio 2002); J.H. France Refractories Co. v. Allstate Ins. Co., 626 A.2d 502, 507 (Pa. 1993).
} 


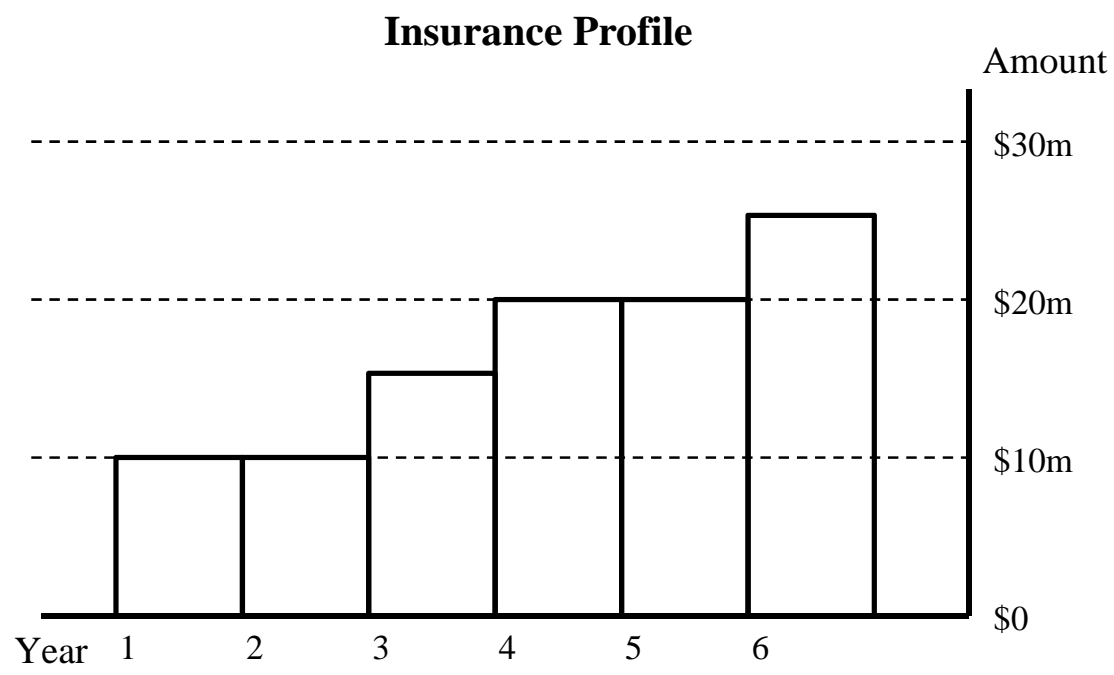

Under the pro rata approach, a court would simply divide the $\$ 30$ million by six, and assign one-sixth of the damages, or $\$ 5$ million, to each policy year:

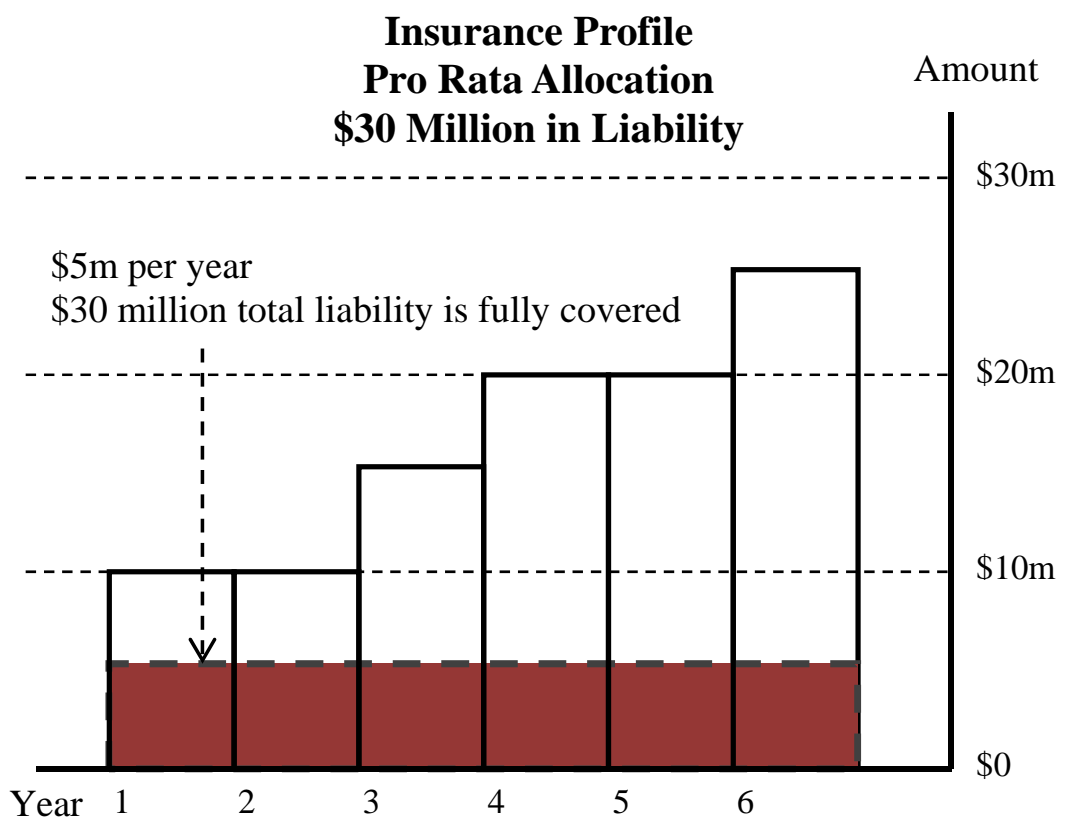

Accordingly, the entirety of the liability would be covered with limits to spare. 
Under the all sums approach, however, the damages are not spread over the property damage period. Instead, the policyholder gets to pick any triggered year to pay for all damages. In this case, the policyholder is likely to attempt to pick the year in which the policies provide the most in limits: Year 6, which has \$25 million in total policy limits. This leaves \$5 million in remaining liability:

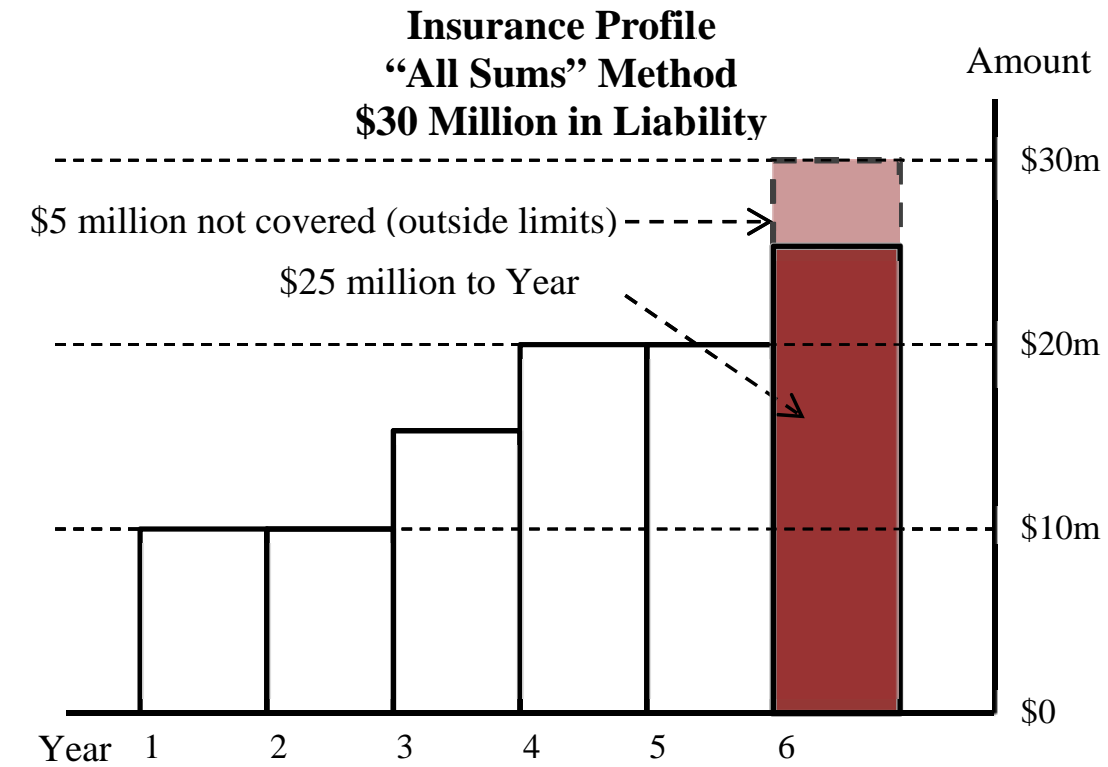

Policyholders then usually contend that they can simply "stack" the policies and recover the remaining damages from policies with periods in another triggered year: 


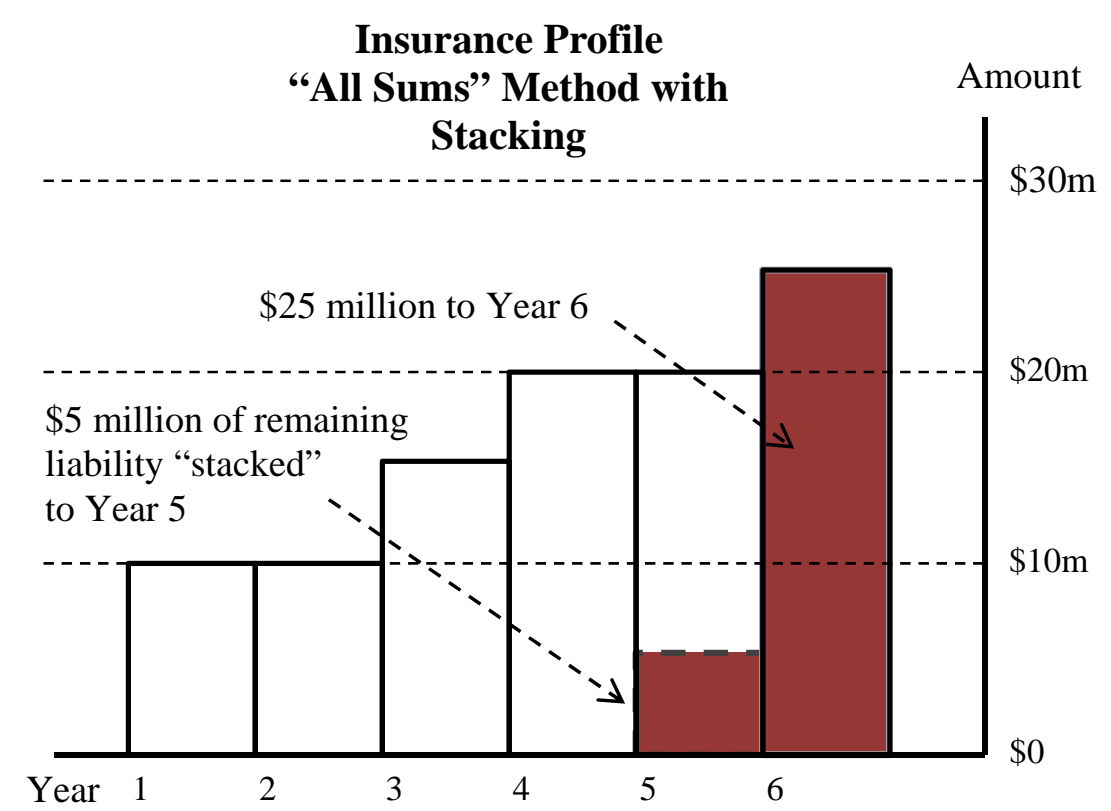

However, under its plain language, the non-cumulation clause prevents the policyholder from doing this. This is because the earlier policies cover the same loss under the all sums approach. Accordingly, the limits of liability of the policies in later years are reduced by the amounts due for the loss from the policies issued in earlier years.

To explain, the plain language of the non-cumulation clause requires the policyholder to initially recover under the policies with periods in the earliest year and work forward. However, the clause reduces the limits of the policies in each succeeding year by the amounts due for the loss from the prior policies. Accordingly, in this scenario, the policyholder would be entitled to $\$ 10$ million under the Year 1 policies. However, under the non-cumulation clause, this "amount due" reduces the limits available under the Year 2 policies to zero. This same \$10 million "amount due" also reduces the limits of the policies in Year 3 by $\$ 10$ million to \$5 million. Under the non-cumulation clause, the policyholder could then recover an additional $\$ 5$ million under the Year 3 policies, or a total of \$15 million. However, the non-cumulation clause would then operate to reduce the limits of the policies in Year 4 (originally $\$ 20$ million) to $\$ 5$ million, because the "amount due" under the prior policies is $\$ 15$ million. The clause would then permit the policyholder to recover an additional $\$ 5$ million under the Year 4 policies, resulting in a total of $\$ 20$ million. However, under the non-cumulation clause, this "amount due” reduces the limits available under the policies in Year 5 (originally 
$\$ 20$ million) to zero. The non-cumulation clause would also reduce the limits of liability available under the policies in Year 6 (originally \$25 million) to $\$ 5$ million. When the policyholder has recovered that sum, it has recovered \$25 million. However, at this point, the non-cumulation clauses have reduced the remaining available policy limits to zero:

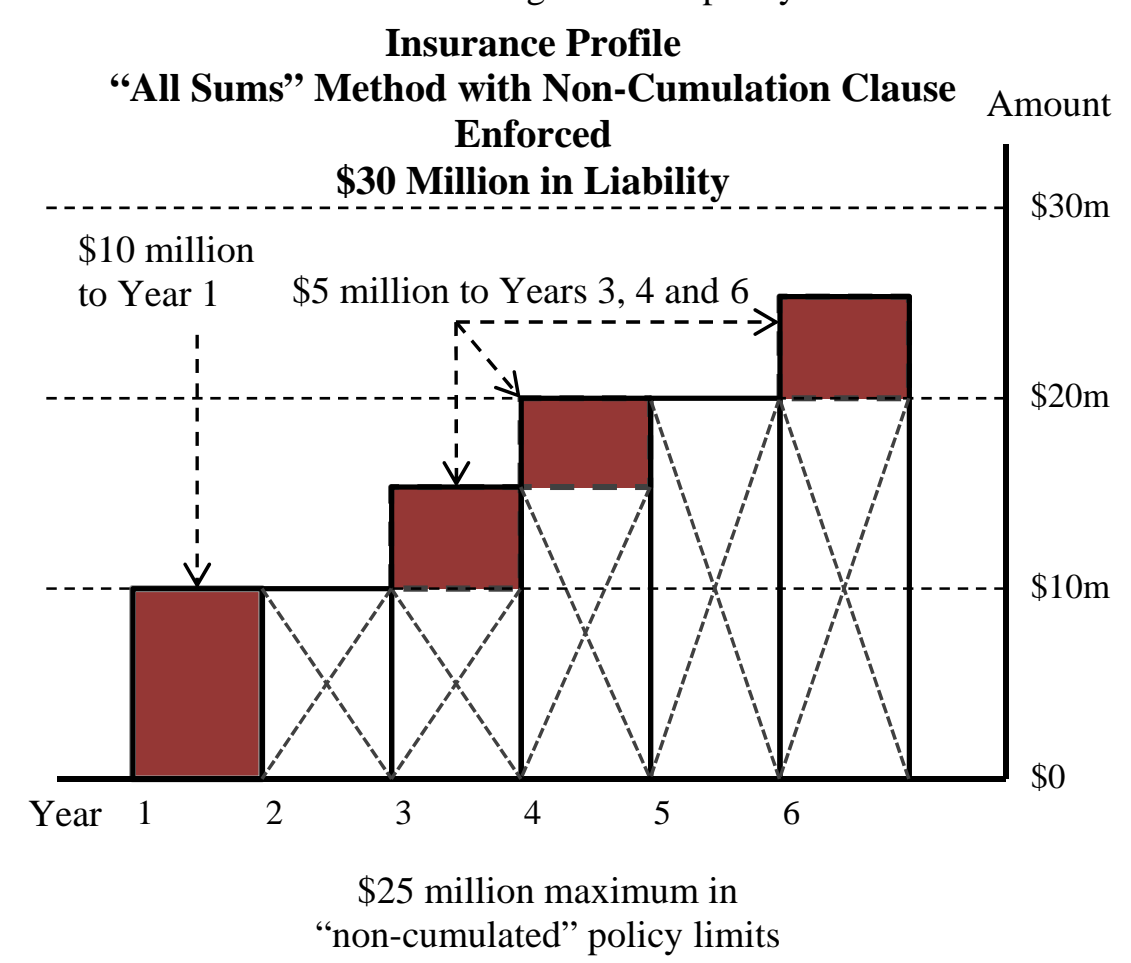

Having used the non-cumulation clause as an argument to support the all sums outcome in some jurisdictions, policyholders are now faced with the disconcerting fact that this same provision, if applied as written, may actually leave them worse off than they would have been if they had simply agreed to the pro rata approach in the first place.

\section{PolicyHolder AtTempts to AVOID the IMPACT Of THEIR PRIOR ARGUMENTS CONCERNING THE NON-CUMULATION CLAUSE}

Policyholders have succeeded in obtaining all sums rulings from a limited number of courts. In doing so, they have often relied on the non- 
cumulation clause as a key argument. ${ }^{84}$ Having achieved their goal in these jurisdictions, however, policyholders and their attorneys have belatedly realized that enforcement of this clause can reduce their recoveries and now seek to avoid the logical outcome of their prior arguments concerning the non-cumulation clause. ${ }^{85}$

This would appear to be the motivating factor behind $\mathrm{Mr}$. Christopher French's recent article, The "Non-Cumulation Clause": An "Other Insurance" Clause by Another Name. ${ }^{86}$ In his article, Mr. French spends considerable space arguing that the non-cumulation clause is ambiguous in the all sums framework. To summarize his primary arguments, Mr. French first asserts that the non-cumulation clause was specifically and narrowly designed solely to address the circumstance in which a prior accident-based policy and a subsequent occurrence-based policy cover the same loss. ${ }^{87}$ He then asserts that the drafters of the noncumulation clause did not contemplate subsequent developments in insurance law, such as the continuous trigger and all sums liability, at the time the clause was written in $1960{ }^{88}$ Mr. French next purports to illustrate the allegedly inconsistent application of the non-cumulation clause in the context of long-tail claims; according to Mr. French, several courts have rejected interpretations of the clause that would eliminate the policyholder's recovery under various theories. ${ }^{89}$ In pro rata jurisdictions, for instance, Mr. French contends that courts have concluded that the application of the clause conflicts with pro rata allocation; however, in all sums jurisdictions, he asserts that courts have rejected the notion that there is an "amount due" under prior insurance where a policyholder's liabilities span multiple policy periods, concluding that there is no amount due under prior insurance unless and until the policyholder presents a claim under those policies. ${ }^{90}$

84. See generally Part V.

85. See, e.g., Cal. Ins. Co. v. Stimson Lumber Co., No. Civ. 01-514-HA, 2004 WL 1173185, at *32 (D. Or. May 26, 2004), aff'd in part, rev'd in part, 325 F. App’x 496 (9th Cir. 2009) (finding that the non-cumulation clause reduced the insurer's policy limits by amounts paid in prior policy years or the amounts paid by other excess insurers where excess insurance coverage was available); Endicott Johnson Corp. v. Liberty Mut. Ins. Co., 928 F. Supp. 176, 181-82 (N.D.N.Y. 1996) (finding that a non-cumulation clause precluded policyholder from recovering more than one policy limit); Viking Pump, Inc. v. Century Indem. Co., 2 A.3d 76, 122 (Del. Ch. 2009) (holding that a noncumulation clause prevented a policyholder from seeking more than one year's set of per-occurrence limits for a given occurrence).

86. See French, supra note 9.

87. Id. at 386-87.

88. Id. at 387 .

89. Id. at 389-90.

90. Id. at 391 . 
Mr. French further argues that the application of the non-cumulation clause would enable insurers to "escape" liability by "deflect[ing]" coverage responsibility to defeat a policyholder's recovery. ${ }^{91}$ In support of this contention, Mr. French cites to case law in which courts in all sums jurisdictions have invalidated "other insurance" provisions appearing in successive policies. ${ }^{92}$

In Mr. French's view, the apparent inconsistencies in the application of the non-cumulation clause with respect to long-tail claims, as well as their purported incongruity under both the all sums and pro rata allocation approaches, necessarily render these clauses inherently ambiguous. ${ }^{93}$ In making these arguments, Mr. French focuses on isolated parts of the non-cumulation clause and brands them as ambiguous. ${ }^{94} \mathrm{Mr}$. French further contends that the clauses are unenforceable under the "reasonable expectations" doctrine, because a policyholder reasonably expects to recover for the entirety of a loss up to the policy limits (notwithstanding the presence of the non-cumulation clause in its policies). ${ }^{95}$ Consequently, according to Mr. French, the non-cumulation clause is "hopelessly ambiguous" and "contrary to the reasonable expectations of the policyholder.",96

Mr. French's arguments simply ignore the fact that policyholders have repeatedly used the non-cumulation clause to argue in favor of all sums liability, contending that the clause proves that insurers have always understood that CGL policies cover injury or damage happening outside their policy periods. ${ }^{97}$ Now, faced with the results of the actual application of the clause in all sums jurisdictions, Mr. French seeks to avoid sleeping in the bed that the policyholders have made by claiming that those who drafted the clause did not anticipate developments like the continuous trigger and all sums liability, and arguing that noncumulation provisions apply only to continuous losses that begin in an accident-based policy period and continue into an occurrence-based policy period. ${ }^{98}$

To put it bluntly, policyholders cannot have their cake and eat it too. If, as the policyholder bar has repeatedly contended, the non-cumulation

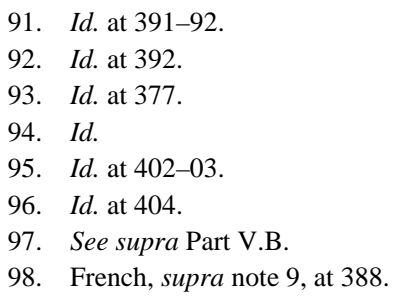


clause supports the all sums approach, then it applies under that approach. If, on the other hand, the clause does not apply because its narrow purpose was to prevent recovery under both accident- and occurrence-based policies, then it is entirely irrelevant to the question of whether the all sums approach or pro rata allocation applies to coverage for long-tail claims.

\section{APPliCATION OF THE NON-CUMULATION CLAUSE IN THE ALL SUMS CONTEXT}

\section{A. The Non-Cumulation Clause Is Unambiguous}

Despite Mr. French's claims to the contrary, the language of the noncumulation clause is clear and unambiguous. The clause was crafted originally to address the situation in which both a prior accident-based policy and a subsequent occurrence-based policy applied to the same loss. However, it was not written to limit its application only to that situation, although it would have been simple enough to have done so if that was its purpose. Rather, the clause was written using language that applies generally to any situation in which both earlier and later policies cover the same loss, regardless of the reason.

The ambiguities that Mr. French seeks to manufacture are inextricably tied to his apparent (and erroneous) presumption that the non-cumulation clause is irreconcilable with the all sums approach. Citing authority for the proposition that courts have deemed policy terms and provisions ambiguous where they are susceptible to "more than one reasonable meaning," Mr. French asserts that the non-cumulation clause is ambiguous "when one attempts to apply [it] to long-tail liability claims." 99 What Mr. French ultimately suggests, however, is not that the clause itself is inherently ambiguous; rather, the purported ambiguities arise only under the premise that non-cumulation clauses are somehow, now, incompatible with the all sums approach, despite years of prior policyholder arguments that their existence supports the all sums approach. At bottom, however, Mr. French's arguments are based on the notion that difficulties in applying a contract provision render the provision ambiguous. There is simply no support for that proposition. In fact, precisely the opposite is true. ${ }^{100}$

\footnotetext{
99. Id. at 398.

100. See, e.g., Drews Distrib., Inc. v. Leisure Time Tech., Inc., No. 97-2391, 1999 WL 183811, at *11-12 (4th Cir. Apr. 5, 1999) (observing that a contract is not ambiguous merely because it is
} 
Moreover, courts across the nation have rejected the proposition that non-cumulation clauses are ambiguous, and have concluded that, by their plain language, these clauses apply under the all sums approach. ${ }^{101}$ For instance, in Stonewall Insurance Co. v. E.I. du Pont de Nemours \& Co., the court recognized that the non-cumulation clause applies in the all sums context and limits the amount a policyholder may seek from a subsequent excess insurer. ${ }^{102}$ Importantly, Stonewall recognized that ambiguities cannot be read into a non-cumulation clause by willfully divorcing its key terms from the context in which they appear in the

difficult to construe); Candid Corp. v. Assurance Co., No. CV054008138, 2007 WL 1120616, at *9 n.5 (Conn. Super. Ct. March 29, 2007) (noting that difficulties in applying a particular contract provision to a given set of factual circumstances do not render the provision itself ambiguous); McCann v. Glynn Lumber Co., 34 S.E.2d 839, 845 (Ga. 1945) (noting that a contract is not ambiguous merely because it may be difficult to construe); Shivvers v. Am. Family Ins. Co., 589 N.W.2d 129, 135 (Neb. 1999) (“[A]n otherwise unambiguous provision is not made ambiguous simply because it is difficult to apply to the facts of a particular case." (quoting Quinlan v. Coombs, 314 N.W. 2d 125, 128 (Wis. Ct. App. 1981)) (internal quotation marks omitted)).

101. See, e.g., Liberty Mut. Ins. Co. v. Treesdale Inc., 418 F.3d 330, 341-44 (3d Cir. 2005) (enforcing a clear and unambiguous non-cumulation clause); Plantation Pipeline Co. v. Cont'l Cas. Co., No. 1:0-CV-2811-WBH, 2008 WL 4737163, at*7 (N.D. Ga. July 31, 2008) (finding that the term "loss" in the non-cumulation clause is not ambiguous when viewed in the context of the clause's remaining language); Cal. Ins. Co. v. Stimson Lumber Co., No. Civ. 01-514-HA, 2004 WL 1173185, at *31-32 (D. Or. May 26, 2004), aff'd in part, rev'd in part, 325 F. App’x 496 (9th Cir. 2009) (adopting insurer's construction of the term "loss" in the non-cumulation clause and enforcing the clause in favor of the insurer); Endicott Johnson Corp. v. Liberty Mut. Ins. Co., 928 F. Supp. 176, 182 (N.D.N.Y. 1996) (enforcing a non-cumulation clause that is clear in both content and title); O-I Brockway Glass Container v. Liberty Mut. Ins. Co., No. Civ. 90-2797 (AET), 1994 WL 910935, at *8 (D.N.J. Feb. 10, 1994) (" $[\mathrm{N}] \mathrm{o}$ confusion or ambiguity exists regarding the Non-Cumulation clause. '[T]he words of an insurance policy should be given their ordinary meaning, and in the absence of an ambiguity, a court should not engage in a strained construction to support the imposition of liability."” (alteration in original) (quoting Longobardi v. Chubb Ins. Co., 582 A.2d 1257 (N.J. 1990))); Air Prods. \& Chems., Inc. v. Hartford Accident \& Indem. Co., Civ. A. No. 867501, 1989 WL 73656, at *6-7 (E.D. Pa. June 30, 1989), aff'd in part, vacated in part, 25 F.3d 177 (3d Cir. 1994) (concluding that there is no basis for failing to enforce the terms of the noncumulation provision); Stonewall Ins. Co. v. E.I. du Pont de Nemours \& Co., 996 A.2d 1254, 1259 (Del. 2010) (agreeing with the motion judge's application of the unambiguous non-cumulation clause); Hercules, Inc. v. AIU Ins. Co., 784 A.2d 481, 493-94 (Del. 2001) (applying a noncumulation clause and "all sums" provisions to determine insurance coverage); Viking Pump, Inc. v. Century Indem. Co., 2 A.3d 76, 127 (Del. Ch. 2009) (emphasizing that the language of the noncumulation clause works precisely in an "all sums" context); Hiraldo v. Allstate Ins. Co., 840 N.E.2d 563, 564-65 (N.Y. 2005) (enforcing a non-cumulation clause); Mark IV Indus. v. Lumbermens Mut. Cas. Co., No. 2005/2029, 2006 N.Y. Misc. LEXIS 1294, at*15 (N.Y. App. Div. Apr. 28, 2006) (holding that the ordinary language of the non-cumulation provision applied).

102. 996 A.2d 1254, 1259-60 (Del. 2010) ("Under the all sums approach, [the insured] may choose a single tower of coverage ... from which to seek indemnity and defense costs. After selecting a tower, coverage then proceeds up the tower from the first layer of coverage until full indemnity or complete exhaustion of the policy limits occurs. In turn, the selected insurers may then seek contribution against other carriers from other towers.... The non-cumulation clause does not create an ambiguity which alters this process.” (emphasis added) (footnotes omitted)). 
policy, thereby "dishonor[ing] the spirit of the clause and improperly allow[ing] [the insured] to obtain a double recovery." "103 Similarly, in Hercules, Inc. v. AIU Insurance Co., the court recognized that noncumulation clauses do not apply in the context of pro rata allocation, but do apply under the all sums approach. ${ }^{104}$ Outboard Marine Corp. v. Liberty Mutual Insurance Co. echoed this principle, holding that noncumulation clauses are unenforceable in the context of pro rata allocation. ${ }^{105}$ Although Mr. French correctly recognizes that Outboard Marine rejected an interpretation of the non-cumulation clause that would reduce the policyholder's recovery, ${ }^{106}$ this rejection was expressly limited to the context of pro rata allocation rather than all sums liability - because pro rata allocation limited each policy's liability to damages happening during its policy period, no policy in any given year was being applied to the same loss as a prior policy. Accordingly, by its terms, the non-cumulation clause did not apply under the pro rata allocation framework. ${ }^{107}$ Outboard Marine's discussion in no way suggests that the non-cumulation clause would not apply under an all sums scheme, as Mr. French seems to suggest. In fact, the contrary is true: if the clause does not apply under the pro rata approach because no policy is being held responsible for the same loss as an earlier policy, then it necessarily does apply under the all sums scheme, which clearly does hold later policies liable for the same loss as earlier policies.

\section{B. The Distinction Between Non-Cumulation and "Other Insurance" Clauses}

Mr. French's attempt to analogize non-cumulation clauses to "other insurance" clauses disregards the clear differences in the purposes and application of these clauses. Mr. French relies wholly on a superficial similarity between the two types of clauses, reasoning that, like other insurance clauses, "[n]on-cumulation clauses... purport to shift the liability for a loss from the policy at issue to other policies issued in prior

\footnotetext{
103. Id. at 1260 .
}

104. Hercules, Inc., 784 A.2d at 494-95. In fact, this prevention of a double recovery aligns precisely with the original purpose of the clause. See supra Part III.

105. 670 N.E.2d 740, 750 (Ill. App. Ct. 1996) (finding it "illogical to enforce” non-cumulation clauses where there was a "continuous occurrence" that could be viewed as a separate occurrence for each policy receiving pro rata allocation).

106. See French, supra note 9, at 389 (noting that the court in Outboard Marine considered applying the non-cumulation clause to be the same as double charging the insurer).

107. Outboard Marine, 670 N.E. 2d at 750 (finding that the non-cumulation clause cannot be enforced if a pro rata allocation has been assessed). 
years, so the same principles apply." ${ }^{108}$ As an initial matter, an other insurance clause cannot be equated directly with a non-cumulation provision-both clauses exist independently of one another and use different terms and conditions. Fundamental principles of contract construction require insurance contracts to be interpreted in their entirety, such that all terms and provisions are given effect. Mr. French's assertion that other insurance and non-cumulation clauses are the same renders one clause or the other mere surplusage, in violation of this cardinal principle. ${ }^{109}$

In fact, other insurance clauses are conceptually different from noncumulation clauses. Specifically, other insurance clauses often apply to concurrent coverage situations, in which two or more policies insuring the same time period cover the same loss. ${ }^{110}$ In contrast, non-cumulation clauses address the situation in which consecutive policies apply to the same loss. ${ }^{111}$

108. French, supra note 9, at 407.

109. See Enter. Tools, Inc. v. Export-Import Bank of the U.S., 799 F.2d 437, 439 (8th Cir. 1986) (stating that "clauses must be read in context," suggesting that an insurance contract must be read as a whole to determine what the parties reasonably intended by its terms); Gfeller v. Scottsdale Vista N. Townhomes Ass'n, 969 P.2d 658, 660 (Ariz. Ct. App. 1998) (where possible, a court should interpret a contract in such a way as to reconcile and give meaning to all of its terms).

Several cases stand specifically for the proposition that all parts and clauses of a policy must be considered together to ascertain the extent to which one clause is explained, modified, or limited by the others. See, e.g., Fibreboard Corp. v. Hartford Accident \& Indem. Co., 20 Cal. Rptr. 2d 376, 386-87 (Cal. Ct. App. 1993) (applying the same meaning to repeated terms); Peerless Ins. Co. v. Brennon, 564 A.2d 383, 384-85 (Me. 1989) (requiring contracts to be construed as a whole); Mont. Petroleum Tank Release Comp. Bd. v. Crumleys, Inc., 174 P.3d 948, 957 (Mont. 2008) (stating that policies must be read as a whole and the various parts reconciled).

110. See, e.g., Schoenecker v. Haines, 277 N.W.2d 782, 783-84 (Wis. 1979).

111. See, e.g., Swainston v. Am. Family Mut. Ins. Co., 774 N.W.2d 478, 482 (Iowa 2009) (citing 12 LeE R. Russ \& ThOMAs F. SEgalla, COUCH ON Insurance § 169:9 (3d ed. 1998)). Although the court in Swainston differentiates "other insurance" clauses and "stacking," noncumulation clauses are often referred to as "anti-stacking" clauses, meaning that they prohibit an insured from "stacking" the limits of multiple policy years to maximize coverage. See Liberty Mut. Ins. Co. v. Treesdale Inc., 418 F.3d 330, 344-45 (3d Cir. 2005) (explaining that the non-cumulation clause, like all anti-stacking clauses, does not eliminate coverage but simply provides that if a single occurrence gives rise to an injury during more than one policy period, only one occurrence limit will apply; as such, it is not an escape clause); Plastics Eng'g Co. v. Liberty Mut. Ins. Co., 466 F. Supp. 2d 1071, 1082 (E.D. Wis. 2006), aff'd, 316 F. App’x 501 (7th Cir. 2009) ("The court finds significant the distinction between concurrent and successive policies. 'Other insurance' provisions ... deal with the situation of concurrent coverage. At issue in the present case is a 'noncumulation' provision, which is intended to address successive policies.”); Air Prods. \& Chems., Inc. v. Hartford Accident \& Indem. Co., No. 86-7501, 1989 WL 73656, at *2 (E.D. Pa. June 30, 1989), aff'd in part, rev'd in part, 25 F.3d 177 (3d Cir. 1994) (finding that non-cumulation clause did not constitute an escape clause given that it sought only to limit, rather than preclude, the insurer's liability for claims against its insured); Spaulding Composites Co. v. Aetna Cas. \& Sur. Co., 819 A.2d 410, 421 (N.J. 2003) ("Because it is well settled that an escape clause is a sub-species of other insurance.... and because a non-cumulation clause is not an other-insurance clause, it 


\section{The Policyholder's “Amounts Due” Argument is Flawed}

As noted previously, Mr. French contends that there is no "amount due" under prior insurance unless and until the policyholder presents a claim under those policies. Thus, according to Mr. French, the noncumulation clause does not apply unless and until such a claim is presented under these earlier policies. ${ }^{12}$ The fundamental flaw in this argument is that it is completely contrary to the all sums approach that the policyholders in these cases are espousing.

Under the all sums scheme, the policyholder typically files a suit seeking coverage under all policies issued during the relevant injury or damage period, and asserts that all of those policies are jointly and severally liable for the loss at issue, subject to their limits of liability. In other words, the very nature of the all sums theory means that the policyholder is asserting that there are "amounts due" for the loss under all policies, at the inception of the case.

Additionally, Mr. French's argument ignores the meaning of the word "due." Under the appropriate definition, "due" means "owed" or "owing as a debt." Again, the very nature of the all sums argument is that all policies on the risk during the relevant timeframe owe coverage to the policyholder. The notion that there are no "amounts due" under the earlier policies until the policyholder presents a claim therefore is directly contrary to the all sums theory and to the policyholders' complaints in these cases.

Moreover, this argument conflicts with Mr. French's position that the purpose of the non-cumulation clause was to prevent an "accident-" based policy and an "occurrence-" based policy from covering the same

follows that a non-cumulation clause technically is not an escape clause.”). The recent ruling in Mt. McKinley Insurance Co. v. Corning Inc., Index No. 602454/2002 (N.Y. App. Div. Sept. 7, 2012), rejected the application of a non-cumulation clause in the "all sums" context, but did so based on a misapprehension of the nature of the clause. Attempting to distinguish the Delaware Chancery court's holding in Viking Pump v. Century Indem. Co., 2 A.3d 76 (Del. Ch. 2009), that noncumulation clauses applied in an "all sums" context, Corning emphasized the fact that the "other insurance" clauses at issue in the case before it applied only to concurrent coverage and, thus, did not mandate joint and several liability. Mt. McKinley, Index No. 602454/2002, at 50. The court implicitly grouped non-cumulation clauses and the "other insurance" clauses at issue together for purposes of its analysis, and in doing so erroneously assumed that non-cumulation clauses apply only in the concurrent coverage context. Id.

112. French, supra note 9, at 391.

113. See Due, MERRIAM-WEBSTER DiCTIONARY, http://www.merriam-webster.com/dictionary/ due (last visited Mar. 20, 2013). 
loss. ${ }^{114}$ Nothing would prevent a policyholder from employing the same amounts due argument, which Mr. French seeks to employ in order to avoid application of the clause as between occurrence-based policies, in order to circumvent the clause in the very context in which he concedes it is designed to apply. ${ }^{115}$ If policyholders can select the order in which to target occurrence-based policies to avoid the non-cumulation clause, there is no reason that they could not do the same with respect to accident and occurrence policies-target the occurrence-based policy with a non-cumulation clause first, and then the earlier accident-based policy. This argument thus leads to the very result that Mr. French concedes the non-cumulation clause was designed to prevent in the first place.

In sum, the interpretation of when amounts are "due" that Mr. French advocates would allow a policyholder to unilaterally circumvent the noncumulation provision by manipulating the sequence in which it selects policy years to pay for a loss, thus rendering the provision meaningless. Various courts have rejected this argument on this basis. ${ }^{116}$

\section{The Non-Cumulation Clause and Pro Rata Allocation}

At bottom, many of the problems that Mr. French alleges with noncumulation clauses stem from the fact that the CGL policy language limits coverage to damages on account of injury or damage during the policy period. When that limitation is honored-by pro rata allocation, for instance- then the non-cumulation clause does not apply, because no earlier policy is covering the same loss as a later policy; each policy is only insuring the loss attributable to the injury or damage happening during its policy period. When the policy language is honored, the noncumulation clause might generally be relegated to the accident-based versus occurrence-based situation and, in any event, would not apply to long-tail claims. Unfortunately, policyholders are the victims of their own, limited success in persuading certain jurisdictions to adopt the all sums approach. In those jurisdictions, policyholders have succeeded in persuading the courts that the long-tail claim situation is precisely the

\footnotetext{
114. French, supra note 9 , at 387-88.

115. Id. at 391.

116. See, e.g., Endicott Johnson Corp. v. Liberty Mut. Ins. Co., 928 F. Supp. 176, 181-82 (N.D.N.Y. 1996) (finding that the relevant non-cumulation clause was not ambiguous, and therefore plaintiff could not "stack"); O-I Brockway Glass Container, Inc. v. Liberty Mut. Ins. Co., No. Civ. 90-2797 (AET), 1994 WL 910935, at*7-10 (D.N.J. Feb. 10, 1994) (rejecting the policyholder's argument that it could invoke coverage in reverse chronological order).
} 
same as the accident-based versus occurrence-based situation-earlier and later policies covering the same, undifferentiated loss. Having converted the long-tail claim situation into precisely the same situation that gave rise to the non-cumulation clause, policyholders can hardly cry foul when the clause is applied to the situation that their arguments created. This conclusion is borne out by the decisions addressing the application of non-cumulation clauses in pro rata allocation jurisdictions. ${ }^{117}$

\section{CONCLUSION}

Courts have long contended with determining how best to apportion liability for long-tail claims. Difficulties in proving the cause and progression of injury or damage with respect to such claims have sparked much debate. To persuade the courts to maximize their recoveries by rejecting pro rata allocation, policyholders have contended that the existence of the non-cumulation clause demonstrates that CGL insurers contemplated all sums liability. Now, in an attempt to undermine the application of the non-cumulation clause in that very same all sums context, Mr. French claims that those who drafted the clause did not anticipate certain developments, such as all sums liability, and argues that the clause applies only to continuous losses that implicate both accident-based and occurrence-based policies. In so arguing, Mr. French disregards the fact that policyholders have repeatedly used the noncumulation clause to support their all sums arguments. Under its plain terms, the clause applies generally to any situation in which both earlier and later policies cover the same loss, and several jurisdictions have applied the clause to reduce policyholders' recoveries under the all sums regime. Mr. French's attempts to manufacture ambiguity in the clause stem solely from perceived difficulties in applying the clause to the all sums approach, and his arguments disregard the ample authority holding that the non-cumulation clause is unambiguous. Nor can non-cumulation clauses be equated with other insurance clauses in light of clear differences in their purposes and application.

117. See Viking Pump, Inc. v. Century Indem. Co., 2 A.3d 76, 123 (Del. Ch. 2009) (reasoning that after application of pro rata allocation, the "very premise upon which the [n]on-[c]umulation ... provision[] [is] based is absent, because there is no common injury"); Outboard Marine Corp. v. Liberty Mut. Ins. Co., 670 N.E.2d 740, 754 (Ill. App. Ct. 1996) (declining to give effect to noncumulation clause under a pro rata allocation scheme); Spaulding Composites Co. v. Aetna Cas. \& Sur. Co., 819 A.2d 410, 422 (N.J. 2003) (explaining that once a court adopts pro rata allocation, the non-cumulation clause "drops out" of the policy). 
Simply put, if, as policyholders contend, the non-cumulation clause supports an all sums approach, then it must apply under that approach. If Mr. French is right, and the clause does not apply in the all sums context, then the clause does not support all sums liability in the first place. 